Gertrude C. Davis, Head Librarian, Martha S. Grafton Library, Mary Baldwin College, Staunton, Virginia

Secretary

Joel M. Lee, Head of Technical Services, Donnelley Library, Lake Forest College, Lake Forest, Illinois

Brother Paul J. Ostendorf, Head Librarian, Fitzgerald Library, Saint Mary's College, Winona, Minnesota

\section{COMMUNITY AND JUNIOR COLLEGE LIBRARIES SECTION}

\section{Vice-Chairman/Chairman-Elect}

Imogene I. Book, Director of the Library, Rend Lake College, Ina, Illinois

Bob Schremser, Head Librarian, Alexander City State Junior College, Alexander City, Alabama

\section{Secretary}

William I. Bunnell, Director of Library Services, County College of Morris, Dover, New Jersey

Raymond G. Roney, Director of the Library, Washington Technical Institute, Washington, D.C.

\section{EDUCATION AND BEHAVIORAL SCIENCES SECTION}

Vice-Chairman/Chairman-Elect

Darrell Jenkins, Assistant Serials Librarian, New Mexico State University, Las Cruces, New Mexico
Jean C. Jones, Librarian, American Psychiatric Museum Association, Washington, D.C.

Secretary

Leslie Benton Bjorncrantz, Curriculum Librarian and Reference Librarian, Northwestern University, Evanston, Illinois

Marjorie Zumstein, Education and Psychology Librarian, Purdue University, West Lafayette, Indiana

\section{LAW AND POLITICAL SCIENCE SECTION}

\section{Vice-Chairman/Chairman-Elect}

Susan C. Finsen, Assistant Executive Officer, Congressional Research Service, Library of Congress, Washington, D.C.

Myron Jacobstein, Law Librarian, Stanford University Law Library, Stanford, California Member-at-Large

Frances Hunt Hall, Law Librarian and Associate Professor, Law Library, Southern Methodist University, Dallas, Texas

Leslie W. Sheridan, Director of University Libraries, The University of Toledo, Toledo, Ohio

\section{RARE BOOKS AND MANUSCRIPTS SECTION}

Vice-Chairman/Chairman-Elect

Evert Volkersz, Head, Department of Special Collections, State University of New York at Continued on page 320

\title{
News From the Chapters
}

The Eastern New York Chapter of ACRL held its fall meeting at the State University of New York at Cortland on October 1, 1976.

The meeting consisted of seven roundtable discussions which were available in both morning and afternoon sessions. The group leaders were drawn from the chapter, thus providing an opportunity for the membership to utilize its expertise in various areas of librarianship.

The topics discussed were "Minicomputers in Libraries," led by.John Linford, State University of New York at Albany; "Library Instruction," Lynn Case and Jon Lindgren, St. Lawrence University, Canton, New York; "Public Relations and Orientation," Jacquelyn Gavryck, SUNY, Albany; "Which Services and to Whom," Irving Stephens, Rensselaer Polytech- nic Institute, Troy, New York; "Weeding Library Collections," Mina LaCroix and Barbara Rice, SUNY, Albany; "Budgeting for Library Acquisitions," Sue Weaver, St. Lawrence University; and "Interlibrary Loan," Lee Dalzell, Williams College, Williamstown, Massachusetts.

Comments solicited on a questionnaire distributed by the Program Planning Committee indicate that the informal nature of the program was conducive to productive group discussion and that the format should be repeated next year.

Evaluative interviewing will be the subject of the spring meeting to be held at Williams College on May 26, 1977. Sheila Creth of the University of Connecticut, Storrs, will be the featured speaker. 